DOI https://doi.org/10.33766/2524-0323.86.136-146

УДК 342.951+343.346

В. М. Панькевич,

кандидат юридичних наук, доцент кафедри правознавства

Вінницького торговельно-економічного інституту КНТЕУ (м. Вінниця, Україна) e-mail: vasiliy2112@ukr.net (iD https://orcid.org/0000-0003-0298-0033

А. М. Безносюк, кандидат юридичних наук, доцент кафедри правознавства Вінницького соціально-економічного інституту університету «Україна» (м. Вінниця, Україна) e-mail: beznosuk.mia@gmail.com (iD https://orcid.org/0000-0003-1158-57

\title{
ОСОБИ, ЩО КЕРУЮТЬ ОКРЕМИМИ ВИДАМИ ЕЛЕКТРОТРАНСПОРТУ, ЯК СУБ'ЄКТИ ВІДПОВІДАЛЬНОСТІ У СФЕРІ ЗАБЕЗПЕЧЕННЯ БЕЗПЕКИ ДОРОЖНЬОГО РУХУ
}

У статті розглянуто питання вдосконалення законодавства у сфері забезпечення безпеки дорожнього руху стосовно осіб, що керують окремими видами електротранспорту. Авторами запропоновано внесення змін до Закону України «Про дорожній рух» та постанови Кабінету Міністрів України № 1306 від 10 жовтня 2001 р. щодо віднесення до учасників дорожнього руху вищезазначених осіб. Крім цього, пропонується розглянути доцільність розширення переліку транспортних засобів категорії А1 окремими видами електротранспорту (враховуючи їх максимальну швидкість руху, вантажопідйомність тощо), що будуть підлягати реєстрації та отриманню посвідчення водія.

Ключові слова: електротранспорт, водій, безпека дорожнього руху, правила дорожнього руху, юридична відповідальність за порушення у сфері безпеки руху.

Постановка проблеми. Безпека дорожнього руху та заходи по іï забезпеченню є пріоритетним напрямком діяльності держави з огляду на зміст статті 3 Конституції України, де людина, ії життя і здоров'я, безпека визнаються в Україні найвищою соціальною цінністю. Статистичні дані за сім місяців 2019p. у порівнянні з минулим роком демонструють виключну важливість вживання з-боку держави своєчасних та ефективних заходів 3 метою зменшення автотранспортних пригод. Так, за даними Департаменту патрульної поліції НПУ за вказаний період сталося 86702 дорожнотранспортних пригод (далі - ДТП) (минулий рік - 81 006), $з$ них ДТП $з$ постраждалими - 13352 (минулий рік - 12 090), де загинуло 1688 осіб (минулий рік - 1545), а травмовано 16921 особа (минулий рік - 15 647) [1]. Фактично в Україні щодняв ДТП гине 8-9 людей. Тому вжиття з боку держави та інших зацікавлених суб'єктів всіх можливих заходів задля

(ㄷ) Панькевич В. М., 136

Безносюк А. М., 2019 
зупинення цієї жахливої тенденції обумовлює виключну актуальність обраної для дослідження тематики.

Аналіз останніх досліджень i публікацій. У працях ученихадміністративістів уже розроблялася тема вдосконалення адміністративного законодавства у сфері безпеки руху, серед них є наступні: Д. М. Бахрах, О.О. Бандурка, Ю. П. Битяк, В. М. Бевзенко, М. Ю. Веселов, С. М. Гусаров, Т. О. Гуржій, В. В. Єгупенко, В. В. Зуй, Р. І. Михайлов, А. М. Подоляка, В. О. Продаєвич, О. Ю. Салманова, М. О. Свірін, О. М. Соловйова, М. М. Стоцька, Ю. М. Старілов, В. П. Тимощук, Ю. О. Тихомиров та інші. Кримінально-правові проблеми кримінальних правопорушень у сфері безпеки руху та експлуатації транспорту були предметом дослідження вітчизняних учених С. В. Бабаніна, О. О. Балобанова, В. І. Борисова, С. В. Гізімчука, В. С. Гуславського, В. В. Доненка, В. І. Касинюка, 3. Г. Корчевої, О. М. Котовенка, В. А. Мисливого, О. В. Негодченка, О. М. Опальченка, В. I. Осадчого, В. М. Прусса, В. П. Тихого та інших. Разом з цим розвиток науково-технічного прогресу щодо створення нових засобів пересування, особливо, тих, що використовують електричні двигуни, обумовлює актуальність подальших наукових розвідок.

Формування цілей. Метою статті є розгляд питання вдосконалення законодавства щодо визначення правового статусу осіб, які керують окремими видами електротранспорту, як суб'єктів відповідальності у сфері забезпечення безпеки дорожнього руху.

Виклад основного матеріалу. Законодавства в сфері забезпечення безпеки дорожнього руху характеризується значною кількістю несистематизованих нормативно-правових актів різної юридичної сили, а те, що встановлює юридичну відповідальність за правопорушення у цій сфері, високим ступенем бланкетності. При цьому ключову роль у сфері забезпечення безпеки дорожнього руху, незважаючи на свій підзаконний характер, відіграють Правила дорожнього руху (далі - Правила), що затверджені постановою Кабінету Міністрів України № 1306 від 10 жовтня 2001 p. [2].

Відповідно до розділу I «Загальні положення» цього нормативноправового акту, Правила, відповідно до Закону України «Про дорожній рух», встановлюють єдиний порядок дорожнього руху на всій території України. Інші нормативні акти, що стосуються особливостей дорожнього руху (перевезення спеціальних вантажів, експлуатація транспортних засобів окремих видів, рух на закритій території тощо), повинні грунтуватися на вимогах цих документів. Учасники дорожнього руху зобов'язані знати й неухильно виконувати вимоги цих Правил, а також бути взаємно ввічливими.

Отже, обов'язок знати й виконувати цей нормативно-правовий акт покладається не на всіх суб'єктів на території України, а лише на тих, хто є учасниками дорожнього руху. Разом із тим визначення поняття дорожнього руху не міститься ані в Правилах, ані спеціальному законодавчому акті Законі України «Про дорожній рух» (далі - Закон) [3], що не сприяє однообразності та ефективності правозастосування норм цієї сфери, які 
закріплені в різних сферах вітчизняного законодавства. Натомість в енциклопедичній літературі, зокрема, Великому тлумачному словнику сучасної української мови, дорожній рух визначається як процес руху по дорогах транспортних засобів та учасників дорожнього руху; сукупність суспільних відносин, що виникають у процесі переміщення людей і вантажів за допомогою транспортних засобів або без таких у межах дороги [4, с. 204].

Таким чином, дорожнім рухом $є$ переміщення таких речей матеріального світу, як транспортні засоби та учасники дорожнього руху не в просторі взагалі, а лише в межах дороги. Знову ж таки, вищезазначені нормативно-правові акти не містять визначення поняття дороги, а оперують виключно поняттям автомобільної дороги, яке визначається в них порізному. Так Закон визначає автомобільну дорогу (вулицю) як частину території, у тому числі, у населеному пункті, призначену для руху транспортних засобів і пішоходів, з усіма розміщеними на ній спорудами. Цей же нормативно-правовий акт містить класифікацію автомобільних доріг: дороги загального користування, відомчі та приватні. У свою чергу, автомобільні (позаміські) дороги загального користування поділяються на дороги державного та місцевого значення. Автомобільні дороги державного значення поділяються на магістральні та інші. У містах вулиці та дороги поділяються на магістральні вулиці та дороги, дороги та вулиці місцевого значення.

Правила під автомобільною дорогою визначають частину території, зокрема, у населеному пункті, з усіма розташованими на ній спорудами (мостами, шляхопроводами, естакадами, надземними і підземними пішохідними переходами) та засобами організації дорожнього руху, призначену для руху транспортних засобів і пішоходів та обмежену по ширині зовнішнім краєм тротуарів чи краєм смуги відводу. Цей термін включає також спеціально побудовані тимчасові дороги, крім довільно накатаних доріг (колій). Тобто не всі сухопутні території, по яких можливий рух учасників дорожнього руху, мають відношення до автомобільної дороги, зокрема, до цієї категорії не належить накатана дорога в полі, болоті, пустелі, лісі тощо.

Закон містить загальне визначення поняття учасників дорожнього руху - це особи, які використовують автомобільні дороги, вулиці, залізничні переїзди або інші місця, призначені для пересування людей та перевезення вантажів за допомогою транспортних засобів. Також Закон обмежує коло учасників дорожнього руху п'ятьма категоріями: водіями, пасажирами транспортних засобів, пішоходами, велосипедистами та погоничами тварин. Правила, окрім зазначених вище, містять ще одну категорію, що відноситься до учасників дорожнього руху, - особу, яка рухається в кріслі колісному.

До категорії пішоходів Правила відносять осіб, які беруть участь у дорожньому русі поза транспортними засобами і не виконують на дорозі будь-яку роботу. До пішоходів прирівнюються також особи, які рухаються в кріслах колісних без двигуна, ведуть велосипед, мопед, мотоцикл, везуть санки, візок, дитячу коляску чи крісло колісне. Водієм, відповідно до Правил, $\epsilon$ особа, яка керує транспортним засобом i має посвідчення водія 
(посвідчення тракториста-машиніста, тимчасовий дозвіл на право керування транспортним засобом, тимчасовий талон на право керування транспортним засобом) відповідної категорії, а також особа, яка навчає керуванню транспортним засобом, перебуваючи безпосередньо в транспортному засобі. При цьому, під транспортним засобом слід розуміти пристрій, призначений для перевезення людей і (або) вантажу, а також встановленого на ньому спеціального обладнання чи механізмів. Правила містять визначення наступних категорій транспортних засобів: автобус, автопоїзд, вантажний автомобіль, велосипед, легковий автомобіль, маршрутні транспортні засоби, механічний транспортний засіб (транспортний засіб, що приводиться в рух 3 допомогою двигуна. Цей термін поширюється на трактори, самохідні машини й механізми, а також тролейбуси та транспортні засоби з електродвигуном потужністю понад 3 кВт), мопед (двоколісний транспортний засіб, який має двигун із робочим об'ємом до 50 куб.см або електродвигун потужністю до 4 кВТ), мотоцикл (двоколісний механічний транспортний засіб з боковим причепом або без нього, що має двигун з робочим об'ємом 50 куб.см і більше). При цьому розвиток технологій виготовлення електротранспорту дозволяє придбати у торгівельній мережі наступні їх види: електроскутери, електровелосипеди, електросамокати, гіроборди, гіроскутери, моноколеса, електроскейти, дрифт-карти, електроцикли, електробайки, електроквадроцикли та дитячі електроавтомобілі (далі - електричні засоби пересування) [5].

Формально всі ці засоби пересування можна віднести до категорії транспортних засобів, але, відповідно до ст.15 Закону України «Про дорожній рух», такий транспорт не підпадає під жодну з визначених категорій. При цьому практично всі вищенаведені засоби пересування мають електродвигун потужністю менше 3 кВт, тому не є механічними транспортними засобами. Єдиний вид транспортного засобу, до якого формально можливо віднести частину цього електротранспорту, за умови двоколісної конструкції, є мопед, який конструктивно надає водієві можливість керувати ним сидячи, а от електросамокати, гіроборди та гіроскутери такої конструктивної можливості не мають. До того ж мопеди, на відміну від зазначеного транспорту, підлягають державній реєстрації та вимагають наявності в особи, що ним керує, посвідчення водія категорії А 1. Щодо моноколіс, електроскейтів, дрифткартів, електроциклів, електроквадроциклів та дитячих електроавтомобілі, то вони, навіть формально, через більшу, ніж два колеса, конструкцію, не підпадають під поняття мопеда. При цьому в торгівельній мережі пропонують для продажу дитячі електроавтомобілі, що за своїми технічними характеристиками здатні розвинути швидкість до 40 км/год., що є швидшою, ніж у деяких мопедів [6]. Таким чином, особу, що керує зазначеним транспортом, не можна віднести до категорії водіїв, адже, окрім керування транспортним засобом, водій повинен має посвідчення водія (посвідчення тракториста-машиніста, тимчасовий дозвіл на право керування транспортним засобом, тимчасовий талон на право керування транспортним засобом) відповідної категорії. Також вищезазначених осіб чинне законодавство не дозволяє віднести до інших категорій учасників дорожнього руху. 
Разом $з$ тим Правила дорожнього руху закріплюють обов'язки в сфері забезпечення дорожнього руху лише за такими учасниками дорожнього руху як водії механічних транспортних засобів, пасажири, пішоходи, велосипедисти, особи, які керують гужовим транспортом та погоничі тварин. До жодної з названих категорій, особи, що керують вищезазначеними електричними засобами пересування, 3 тих чи інших технічних або юридичних причин віднести не можна. Отже, ми маємо ситуацію, коли в умовах гіпершвидкого розширення кола власників окремих видів електротранспорту, що спроможний розвивати швидкість понад 100 км/год та перевозити більше однієї людини, осіб, що керують такими засобами пересування, не віднесено до учасників дорожнього руху та не поширено на них дію Правил дорожнього руху. Така ситуація може бути віднесена до такого юридичного феномену як прогалина законодавства, що змушує правозастосовну, у тому числі, судову практику використовувати аналогію законодавства. Разом із тим, така правозастосовна практика в цій сфері не відповідає вимогам законодавства, адже Кримінальний кодекс України містить чітку заборону про застосування цього правового інституту, а такий принцип адміністративної відповідальності як законність, теж не допускає застосування аналогії законодавства [7].

У практичній площині прогалина правового регулювання щодо визначення юридичного статусу осіб, що керують згаданими вище електричними засобами пересування, не дозволяє віднести їх до суб'єктів кримінального правопорушення, відповідальність за яке передбачено ст.291 КК України, навіть за умови їх осудності та досягнення ними 16-річного віку на момент вчинення такого правопорушення. Адже вітчизняне правове поле не містить правил користування такими видами електротранспорту, що, у свою чергу, унеможливлює кваліфікацію дій таких осіб за ст. 291 КК України як спеціальної норми. Тому наразі такі дії, у випадку спричинення тяжких наслідків у вигляді тяжких тілесних ушкоджень, у тому числі, що призвели до загибелі людей, можуть кваліфікуватися виключно за ст. 128 КК України, що є кримінальним правопорушенням невеликої тяжкості та передбачає більш м'яке покарання, ніж санкція ст. 291 КК України. Зазначена ситуація, на нашу думку, є прикладом порушення принципу законності як у кримінальному праві, так і принципів кримінально-правової кваліфікації кримінальних правопорушень, зокрема, принципів законності, об'єктивності та точності при кваліфікації кримінальних правопорушень [8, с. 16; 9, с. 59-61, 63].

В умовах правової невизначеності юридичного статусу осіб, що керують електричними засобами пересування, показовою, у контекстіі хибності шляху судової практики, є ухвала Шосткинського міськрайонного суду Сумської області про звільнення від кримінальної відповідальності особи, що вчинила кримінальне правопорушення, передбачене ст. 291 КК України. Згідно обставин справи, а саме: 09.08.2015 року близько 12-00 год. 20 хв. по вул. Шевченка м. Шостка Сумської області в районі буд. № 57 ОСОБА 2, керуючи велосипедом Formula, на порушення вимог п.п. 10.1., 10.2. Правил дорожнього руху, не слідкувала за дорожньою обстановкою, знехтувала власною безпекою 
i, коли виїхала на проїжджу частину, щоб переправитися на протилежний бік, не надала дорогу електровелосипеду Mustang під керуванням ОСОБА 3 та допустила 3 нею зіткнення. ОСОБА 3 , у свою чергу рухалася збоку вулиці Фабричної м. Шостка і мала перевагу руху, однак при виникненні небезпеки для руху мала технічну можливість уникнути ДТП; внаслідок чого в ії діях вбачається порушення вимог п.12.3 Правил дорожнього руху. Через ДТП ОСОБА 3 отримала тілесні ушкодження середньої тяжкості [10]. Таким чином, в ухвалі суду особа, що керувала електровелосипедом марки Mustang, визнана учасником дорожнього руху - велосипедистом, хоча відповідно до Правил дорожнього руху, велосипед є транспортним засобом, крім крісел колісних, що приводиться в рух мускульною силою людини, яка знаходиться на ньому, та не передбачає наявності електродвигуна.

Не краща ситуація склалася в сфері застосування судами адміністративної відповідальності до осіб, що керують електричними засобами пересування. Так постановами Амур-Нижньодніпровського районного суду міста Дніпропетровська від $31.10 .2018 \mathrm{p}$. у справі №199/7835/18, Луганського апеляційного суду від 11 грудня 2018 р. у справі №420/1414/18, Деснянського районного суду м. Києва від 14 січня 2019 р. у справі № 754/17982/18, Чернівецького апеляційного суду від 04 березня 2019 р. у справі №727/8355/18, справи щодо осіб, які керували в стані алкогольного сп'яніння електроскутерами та електробайками, закриті за відсутності складу правопорушення через відсутність у чинному законодавстві норм, які б відносили зазначені засоби пересування до транспортних засобів, а осіб, що ними керували, до категорії водіїв [11; 12; 13; 14]. Натомість, постановами Луцького міськрайонного суду Волинської області від 11 жовтня 2018 р. у справі №161/13820/18, залишеною без змін постановою Волинського апеляційного суду від 10 грудня 2018 р., Петропавлівського районного суду Дніпропетровської області від 20 грудня 2018 р. у справі №188/1856/18 визнано винним у вчиненні адміністративного правопорушення, передбаченого ч.1 ст.130 КУпАП особу, яка керувала в стані алкогольного сп'яніння електроскутером [15; 16]. Враховуючи чинне процесуальне законодавство в справах про адміністративні правопорушення, можливості оскарження постанов апеляційної інстанції в касаційному порядку в таких категоріях справ не передбачено, тому отримати зразкове рішення Верховного суду наразі не уявляється можливим, окрім, надання роз'яснень щодо правозастосування з цих питань у вигляді постанови Пленуму цього суду.

Більш критична ситуація, на нашу думку, складеться з 01.01.2020 р., коли набере чинності Закон України № 2617-VIII від 22 листопада 2018 р. «Про внесення змін до деяких законодавчих актів України щодо спрощення досудового розслідування окремих категорій кримінальних правопорушень», яким, окрім іншого, у ст. $286^{-1}$ КК України передбачається кримінальна відповідальність за керування транспортними засобами в стані алкогольного, наркотичного чи іншого сп' яніння або під впливом лікарських препаратів, що знижують увагу та швидкість реакції [17].

3 метою ліквідації прогалин законодавства у сфері забезпечення безпеки дорожнього руху щодо осіб, які керують електричними засобами пересування, 
на нашу думку, потребує внесення негайних змін хоча б постанова Кабінету Міністрів України №1306 від 10 жовтня 2001 р., де до учасників дорожнього руху слід віднести осіб, що керують електровелосипедами, електросамокатами, гіробордами, гіроскутерами, моноколесами, електроскейтами, дрифт-картами, електроциклами, електробайками, електроквадроциклами та дитячими електроавтомобілями (в ідеальній за строками ситуації потребує змін і чинний Закон України «Про дорожній рух»). Крім цього, варто в Правилах дорожнього руху надати визначення кожного з цих видів електротранспорту з їх технічними характеристиками та закріпити права й обов' язки осіб, що ними керують, в окремому розділі, або ж доповнити відповідними змінами назву та зміст розділу 6 «ВИМОГИ ДО ВЕЛОСИПЕДИСТІВ». Також слід розглянути доцільність розширення переліку транспортних засобів категорії А 1 окремими видами електротранспорту (враховуючи їх максимальну швидкість руху, вантажопідйомність тощо), що будуть підлягати реєстрації та отриманню посвідчення водія. Зазначені законодавчі зміни, на нашу думку, дозволять оперативно відреагувати на об'єктивну необхідність щодо правового регулювання швидко розвиваючого та перспективного різновиду транспорту, а також усунуть недоліки правозастосування адміністративної та кримінальної відповідальності в сфері забезпечення безпеки дорожнього руху.

Висновки. Підводячи підсумок, слід зазначити, що заходи, які вживаються державою в сфері забезпечення безпеки дорожнього руху в Україні, є недостатніми, а щорічно зростаюча кількість загиблих та травмованих внаслідок дорожньо-транспортних пригод, відносить цю проблему до таких, що стосуються національної безпеки. Світова промисловість, реагуючи на економічні тренди по збільшенню кількості транспортних засобів, що використовують відновлювальні джерела, щороку створює та збільшує потужність таких видів електротранспорту як електровелосипеди, електросамокати, гіроборди, гіроскутери, моноколеса, електроскейти, дрифт-карти, електроцикли, електробайки, електроквадроцикли, дитячі електроавтомобілі тощо. Натомість державні органи відверто спізнюються з питанням нормативно-правового регулювання засад використання окремих видів електротранспорту, при експлуатації якого може бути завдана значна шкода людям та майну. Отже, Кабінету Міністрів України слід невідкладно розробити і ввести в дію зміни до постанови Кабінету Міністрів України № 1306 від 10 жовтня 2001 р., якими унормувати правовий статус вищезазначених видів електротранспорту та осіб, що ними керують.

\section{Використані джерела:}

1. Статистичні данні Департаменту патрульної поліції НПУ про кількість і наслідки дорожньо-транспортних пригод. URL : http:/ / patrol.police.gov.ua/ statystyka (дата звернення 07.08.2019).

2. Правила дорожнього руху: постанова Кабінету Міністрів Украӥни №1306 від 10 жовтня 2001 р. URL: https://zakon.rada.gov.ua/laws/show/1306-2001$\%$ D0\% BF (дата звернення 08.08.2019). 
3. Про дорожній рух : закон України // Відомості Верховної Ради Украйни (ВВP), 1993, № 31, ст.338. URL : https://zakon.rada.gov.ua/laws/show/3353-12 (дата звернення 07.08.2019).

4. Великий тлумачний словник сучасної української мови. Укл. і голов. ред. В.Т. Бусел. К. Ірпінь. Перун, 2005. 1719 с.

5. Офіційний сайт торгівельної мережі «Алло». URL: https:/ /allo.ua/ua/monocikly-i-segvei (дата звернення 09.08.2019).

6. Офіційний сайт торгівельної мережі «Алло». URL: https:/ / allo.ua/ua/ detskie-jelektromobili/kart-profi-m-4041-5-green-m4041.html?tab=specs (дата звернення 09.08.2019).

7. Щодо порядку застосування нормативно-правових актів у разі існування неузгодженості між підзаконними актами: ^ист Міністерства юстиції України від 30.01.2009p. № H-35267-18. URL: https:// zakon.rada.gov.ua/laws/show/ru/v3526323-09

8. Вознюк А. А. Кримінальне право України. Загальна частина : конспект лекцій. К. : Нац. акад. внутр. справ. «Освіта України», 2016. 236 с.

9. Панов М. І. Загальні засади кваліфікації злочинів : лекція. Х. : Право, 2016. 104 c.

10. Ухвала Шосткинського міськрайонного суду Сумкої області у справі №589/4904/15-K. URL : http://reyestr.court.gov.ua/Review/54833610 (дата звернення 10.08.2019).

11. Постанова Амур-Нижньодніпровського районного суду міста Дніпропетровська від 31.10.2018p. у справі №199/7835/18. URL: http:/ / reyestr.court.gov.ua/Review/77498470 (дата звернення 10.08.2019).

12. Постанова Новопсковського районного суду Луганської області від 23 жовтня 2018p. у справі №420/1414/18. URL: http:/ / reyestr.court.gov.ua/Review/77341465 (дата звернення 10.08.2019).

13. Постанова Деснянського районного суду м. Києва від 14 січня 2019p. у справі №754/17982/18. URL : http://reyestr.court.gov.ua/Review/79180274 (дата звернення 10.08.2019).

14. Постанова Чернівецького апеляційного суду від 04 березня 2019p. у справі №727/8355/18. URL : http:/ / reyestr.court.gov.ua/Review/80290818 (дата звернення 10.08.2019).

15. Постанова Луцького міськрайонного суду Волинської області від 11 жовтня 2018p. у справі №161/13820/18. URL : http:/ / reyestr.court.gov.ua/Review/77045664 (дата звернення 10.08.2019).

16. Постанова Петропавлівського районного суду Дніпропетровської області від 20 грудня 2018 р. у справі №188/1856/18. URL : http:/ / reyestr.court.gov.ua/Review/78753797 (дата звернення 10.08.2019).

17. Про внесення змін до деяких законодавчих актів України щодо спрощення досудового розслідування окремих категорій кримінальних правопорушень : закон України від 22 листопада 2018p. № 2617-VIII // Відомості Верховної Ради (ВВР), 2019, № 17, ст.71. URL : https:/ / zakon.rada.gov.ua/laws/ show/2617-19 (дата звернення 11.08.2019).

\section{References:}

1. Statystychni danni Departamentu patrulnoy politsii NPU pro kilkist i naslidky dorozhno-transportnykh pryhod. URL : http://patrol.police.gov.ua/statystyka (data zvernennya 07.08.2019). 
2. Pravyla dorozhnogo rukhu: postanova Kabinetu Ministriv Ukrayiny \#1306 vid 10 zhovtnya 2001 r. URL: https://zakon.rada.gov.ua/laws/show/1306-2001-\%D0\%BF (data zvernennya 08.08.2019).

3. Pro dorozhniy rukh : zakon Ukrayiny // Vidomosti Verhovnoyi Radyh Ukrayiny (VVR), 1993, \# 31, st.338. URL : https://zakon.rada.gov.ua/laws/show/3353-12 (data zvernennya 07.08.2019).

4. Velykyy tlumachnyy slovnyk suchasnoy ukrayinskoy movy. Ukl. i golov. red. V.T. Busel. K. Irpin. Perun, 2005. 1719 s.

5. Ofitsiynyy sait torhivelnoy merezhi «Allo». URL : https://allo.ua/ua/monocikly-isegvei (data zvernennya 09.08.2019).

6. Ofitsiynyy sait torhivelnoy merezhi «Allo». URL : https://allo.ua/ua/detskiejelektromobili/kart-profi-m-4041-5-green-m-4041.html?tab=specs (data zvernennya 09.08.2019).

7. Shchodo poryadku zastosuvannya normatyvno-pravovykh aktiv u razi isnuvannya neuzhodzhenosti mizh pidzakonnymy aktamy : lyst Ministerstva yustytsii Ukrayiny vid 30.01.2009r. \# N-35267-18. URL: https:/ / zakon.rada.gov.ua/laws/show/ru/v3526323-09

8. Voznyuk A. A. Kryminalne pravo Ukrayiny. Zahalna chastyna : konspekt lekciy. K. : Nats. akad. vnutr. sprav. «Osvita Ukrayiny», 2016. 236 p.

9. Panov M. I. Zahalni zasady kvalifikatsii zlochyniv : lektsiya. H.: Pravo, 2016. 104s.

10. Ukhvala Shostkynskoho miskraionnoho sudu Sumskoi oblasti u spravi \#589/4904/15-k. URL : http://reyestr.court.gov.ua/Review/54833610 (data zvernennya 10.08.2019).

11. Postanova Amur-Nyzhnodniprovskoho raionnoho sudu mista Dnipropetrovska vid 31.10.2018r. u spravi \#199/7835/18. URL : http://reyestr.court.gov.ua/Review/77498470 (data zvernennya 10.08.2019).

12. Postanova Novopskovskoho raionnoho sudu Luhanskoi oblasti vid 23 zhovtnya 2018r. u spravi \#420/1414/18. URL : http://reyestr.court.gov.ua/Review/77341465 (data zvernennya 10.08.2019).

13. Postanova Desnyanskoho raionnoho sudu m. Kyeva vid 14 sichnya 2019r. u spravi \#754/17982/18. URL : http://reyestr.court.gov.ua/Review/79180274 (data zvernennya 10.08.2019).

14. Postanova Chernivetskoho apelyatsiynoho sudu vid 04 bereznya 2019r. u spravi \#727/8355/18. URL : http://reyestr.court.gov.ua/Review/80290818 (data zvernennya 10.08.2019).

15. Postanova Lutskoho miskraionnoho sudu Volynskoi oblasti vid 11 zhovtnya 2018r. u spravi \#161/13820/18. URL: http:/ / reyestr.court.gov.ua/Review/77045664 (data zvernennya 10.08.2019).

16. Postanova Petropavlivskoho raionnoho sudu Dnipropetrovskoi oblasti vid 20 grudnya 2018 r. u spravi \#188/1856/18. URL: http:/ / reyestr.court.gov.ua/Review/78753797 (data zvernennya 10.08.2019).

17. Pro vnesennya zmin do deyakykh zakonodavchykh aktiv Ukrayiny shchodo sproshchennya dosudovoho rozsliduvannya okremykh katehoriy kryminalnykh pravoporushen : zakon Ukrayiny vid 22 lystopada 2018r. \# 2617VIII // Vidomosti Verkhovnoi Rady (VVR), 2019, \# 17, st.71. URL: https:/ / zakon.rada.gov.ua/laws/ show/2617-19 (data zvernennya 11.08.2019) 
Панькевич В. Н., кандидат юридических наук, доцент кафедры правоведения Винницкого торгово-экономического института КНТЭУ

(г. Винница, Украина)

Безносюк А. H., кандидат юридических наук, доцент кафедры правоведения Винницкого социально-экономического института университета «Украина»

(г. Винница, Украина)

\section{ЛИЦА, УПРАВЛЯЮЩИЕ ОТДЕЛЬНЫМИ ВИДАМИ ЭЛЕКТРОТРАНСПОРТА, КАК СУБЪЕКТЫ ОТВЕТСТВЕННОСТИ В СФЕРЕ ОБЕСПЕЧЕНИЯ БЕЗОПАСНОСТИ ДОРОЖНОГО ДВИЖЕНИЯ}

В статье рассмотрены вопросы усовершенствования законодательства в сфере обеспечения безопасности дорожного движения относительно лищ, которые осуществяют вождение отдельными видами электротранспорта. Авторами предложено внести изменения в Закона Украины «О дорожном движении» и постановление Кабинета Министров Украины №1306 от 10 октября 2001 р. относительно причесления к учасникам дорожного движения вышеуказанных лиц. Кроме этого, предлагается рассмотреть целесообразность разширения перечня транспортных средств категории A1 отдельными видами электротранспорта (учитывая их максимальную скорость движения, грузоподйомность и т.п.), которые будут подлежать регистрации и получению удостоверения водителя.

Ключевые слова: электротранспорт, водитель, безопасность дорожного движения, правила дорожного движения, юридическая ответственность за нарушения в сфере безопасности движения.

Pankevich V., candidate of law, associate professor of the department of law Vinnitsa trade and economic institute KNTEU

(Vinnitsa, Ukraine)

Beznosyuk A., candidate of law, associate professor of the department of law Vinnitsa social and economic institute university of Ukraine

(Vinnitsa, Ukraine)

\section{PERSONS MANAGING SEPARATE TYPES OF ELECTRIC TRANSPORT AS SUBJECTS OF RESPONSIBILITY IN THE FIELD OF SAFETY OF ROAD TRAFFIC}

The article deals with the issues of improvement of the legislation in the field of road safety in relation to the persons managing certain types of electric transport. The authors point out that the measures taken by the state in the field of road safety in Ukraine are 
insufficient, and the increasing number of people killed and injured as a result of road accidents attributes this problem to those concerning national security.

The global industry, responding to economic trends in increasing the number of vehicles using renewable sources, annually creates and increases the capacity of such types of electric transport as electric bicycles, electric scooters, gyro-scooters, mono wheels, electric skates, drift cards, electric cycles, electric cycles, electric cycles electric cars and etc.

The authors, on the basis of the analysis of the current legislation, state the fact that there is no regulatory legal basis for the use of certain types of electric transport, which operation can cause significant harm to people and property. The authors are urged to immediately develop and implement amendments to the Law of Ukraine "On Traffic" and the Cabinet of Ministers of Ukraine Resolution No. 1306 of October 10, 2001, which normalize the legal status of the above-mentioned types of electric transport and persons managing them, and provide definitions of each of these types of electric vehicles with their technical characteristics and to consolidate the rights and responsibilities of the persons who manage them in a separate section, or supplement with the appropriate changes the name and content of section 6 "REQUIREMENTS FOR CYCLISTS" the first movement. In addition, it is proposed to consider the feasibility of expanding the list of A1 vehicles by certain types of electric vehicles (taking into account their maximum speed, capacity, etc.), which will be subject to registration and obtaining a driver's license.

Key words: electric transport, driver, traffic safety, traffic rules, legal responsibility for violations in the field of traffic safety.

\section{DOI}

УДК 343.137.5

В. В. Романюк,

кандидат юридичних наук старший викладач кафедри кримінального процесу та організації досудового слідства

Харківського національного університету внутрішніх справ,

(м. Харків, Украина)

e-mail: Witalimon@gmail.com

iD https://orcid.org/0000-0001-6077-4591

\section{ПРОЦЕСУАЛЬНИЙ АСПЕКТ ВИВЧЕННЯ ОСОБИ НЕПОВНОЛІТНЬОГО}

\section{У КРИМІНАЛЬНОМУ ПРОВАДЖЕННІ ЩОДО НЕПОВНОЛІТНІХ}

У статті здійснено дослідження щодо захисту прав, свобод і законних інтересів особи, особливу категорію яких становлять неповнолітні, які вчинили кримінальне правопорушення або суспільно небезпечне діяння, передбачене законом України про кримінальну відповідальність. Встановлено, що така діяльність $є$ пріоритетним завданням кримінального провадження. Зазначене 